\title{
Evaluation of the Physicochemical, Spectral, and Thermal Properties of Sodium Selenate Treated with the Energy of Consciousness (The Trivedi Effect ${ }^{\circledR}$ )
}

\author{
Mahendra Kumar Trivedi ${ }^{1}$, Alice Branton ${ }^{1}$, Dahryn Trivedi ${ }^{1}$, Gopal Nayak ${ }^{1}$, \\ Cathryn Dawn Nykvist ${ }^{1}$, Celine Lavelle ${ }^{1}$, Daniel Paul Przybylski ${ }^{1}$, Dianne Heather Vincent ${ }^{1}$, \\ Dorothy Felger ${ }^{1}$, Douglas Jay Konersman ${ }^{1}$, Elizabeth Ann Feeney ${ }^{1}$, Jay Anthony Prague ${ }^{1}$, \\ Joanne Lydia Starodub ${ }^{1}$, Karan Rasdan ${ }^{1}$, Karen Mie Strassman ${ }^{1}$, Leonid Soboleff ${ }^{1}$, \\ Maire Anne Mayne ${ }^{1}$, Mary M. Keesee ${ }^{1}$, Padmanabha Narayana Pillai ${ }^{1}$, Pamela Clarkson Ansley ${ }^{1}$, \\ Ronald David Schmitz ${ }^{1}$, Sharyn Marie Sodomora ${ }^{1}$, Kalyan Kumar Sethi ${ }^{2}$, Parthasarathi Panda ${ }^{2}$, \\ Snehasis Jana ${ }^{2, *}$ \\ ${ }^{1}$ Trivedi Global, Inc., Henderson, NV, USA \\ ${ }^{2}$ Trivedi Science Research Laboratory Pvt. Ltd., Bhopal, Madhya Pradesh, India
}

Email address:

publication@trivedieffect.com (S. Jana)

${ }^{*}$ Corresponding author

To cite this article:

Mahendra Kumar Trivedi, Alice Branton, Dahryn Trivedi, Gopal Nayak, Cathryn Dawn Nykvist, Celine Lavelle, Daniel Paul Przybylski, Dianne Heather Vincent, Dorothy Felger, Douglas Jay Konersman, Elizabeth Ann Feeney, Jay Anthony Prague, Joanne Lydia Starodub, Karan Rasdan, Karen Mie Strassman, Leonid Soboleff, Maire Anne Mayne, Mary M. Keesee, Padmanabha Narayana Pillai, Pamela Clarkson Ansley, Ronald David Schmitz, Sharyn Marie Sodomora, Kalyan Kumar Sethi, Parthasarathi Panda, Snehasis Jana. Evaluation of the Physicochemical, Spectral, and Thermal Properties of Sodium Selenate Treated with the Energy of Consciousness (The Trivedi Effect ${ }^{\circledR}$ ). Advances in Bioscience and Bioengineering. Vol. 5, No. 1, 2017, pp. 12-21. doi: 10.11648/j.abb.20170501.12

Received: February 6, 2017; Accepted: February 18, 2017; Published: March 7, 2017

\begin{abstract}
Sodium selenate is a common ingredient in nutraceuticals/pharmaceuticals as a source of selenium. The objective of the current study was to evaluate the impact of The Trivedi Effect ${ }^{\mathbb{R}}$ - Energy of Consciousness (Biofield Energy Healing) on the physicochemical, spectral, and thermal properties of The Trivedi Effect ${ }^{\mathbb{B}}$ Treated sodium selenate using various analytical methods such as PXRD, PSD, FT-IR, UV-vis, DSC, and TGA. Sodium selenate was divided into two parts. One part was denoted as the control, while the other part was defined as The Trivedi Effect ${ }^{\circledR}$ - Biofield Energy Treated sample, which received The Trivedi Effect ${ }^{\circledR}$ Treatment remotely from eighteen renowned Biofield Energy Healers. The PXRD analysis of the treated sample showed the significant alteration of the crystallite size in the range of $-16.63 \%$ to $42.9 \%$ compared with the control sample. However, the average crystallite size of the treated sodium selenate was increased by $1.01 \%$ compared with the control sample. The particle sizes $d_{10}, d_{50}$, and $d_{90}$ values of the treated sample were significantly decreased by $6.14 \%, 16.56 \%$, and $18.82 \%$, respectively compared with the control sample. Consequently, the surface area of the treated sample was significantly increased by $10.52 \%$ compared with the control sample. Both control and treated FT-IR spectra indicated the presence of sharp and strong absorption bands at 888 and $887 \mathrm{~cm}^{-1}$, respectively due to the Se=O stretching. The UV-vis spectroscopic analysis displayed that the wavelength for the maximum absorbance of the control and treated sodium selenate were at 204.8 and $204.9 \mathrm{~nm}$, respectively. The TGA of the control and treated samples exhibited two steps of thermal degradation, and the total weight loss was slightly increased by $1.16 \%$ in the treated sample compared with the control sample. The DSC thermograms showed the latent heat of fusion $(\Delta \mathrm{H})$ was significantly elevated by $6.37 \%$ in the treated sample compared with the control sample. The current study revealed that The Trivedi Effect ${ }^{\circledR}$ - Energy of Consciousness (Biofield Energy Healing) might generate a new polymorphic form of sodium selenate which could be more soluble, thermally more

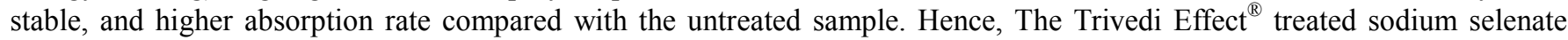
would be very useful to design the various forms of nutraceuticals and/or pharmaceutical formulation which might be providing a better therapeutic response against heart disease (i. e. Atherosclerosis), viral diseases (i. e. Hepatitis), infectious
\end{abstract}


diseases (i. e. Dermatitis, Psoriasis), Parkinson's Disease, Alzheimer's Disease, etc.

Keywords: Biofield Energy Healing Treatment, Biofield Energy Healers, Consciousness Energy Healing, The Trivedi Effect ${ }^{\circledR}$, Sodium Selenate, PXRD, Particle Size, FT-IR, UV-vis, DSC, TGA

\section{Introduction}

Sodium selenate $\left(\mathrm{Na}_{2} \mathrm{SeO}_{4}\right)$ is an important source of an essential trace element selenium (Se) for the human body. Selenium plays an important role in various biological functions such as the catalytic effect on the reaction of metabolic intermediates and inhibits the toxic effect of heavy metals. Selenium is present in the active site of enzymes like glutathione peroxidase and thirty different proteins like selenocysteine. It is a potent antioxidant and is involved in the cellular defense against the free radicals $[1,2]$. Therefore, the deficiency of selenium produces several disorders such as heart disease, viral diseases, infectious diseases, degenerative ailments, etc. As there is a very restricted range between essentiality and toxicity, a little bit high concentration of selenium can affect the human health such as loosing of hair and nails, irritation of skin and eye, cancer, giddiness, depression, and nervousness [1-3]. The activities of selenium depend upon numerous physicochemical and biological factors, as these factors are related to the modifications in its oxidation state. It occurs naturally in four different oxidation states, $i$. e. $-2,0,+4$, and +6 . The different chemical forms of selenium can impact on its solubility and bioavailability to the organisms. Selenate is a most oxidized form of the selenium compounds. It is less toxic and highly soluble in water [1-5]. Sodium selenate is useful for the prevention and treatment of various ailments such as Alzheimer's disease, diabetes, etc. [6-8]. It is also used in the glass industry [9], an ingredient in some insecticides (against mites, aphids, and mealybugs) and some fungicides $[10,11]$. It can be used with vitamin $\mathrm{E}$ in the prevention of a many nutritional deficiency diseases [1]. Selenium methionine is a naturally occurring amino acid and is also the major nutritional source of selenium for the human body. After absorption in the body, inorganic forms of selenium undergo reductive metabolism giving $\mathrm{H}_{2} \mathrm{Se}$, which is responsible for the production of selenoproteins [12]. Hence, sodium selenate is used as one of the constituents in a new proprietary herbomineral formulation as supplement of selenium ion along with the ashwagandha root extract and other essential minerals such as zinc and magnesium, which are commonly used as nutraceuticals for the prevention and treatment of various disorders.

The human being can emit the electromagnetic waves in the form of bio-photons that surrounds the body. This electromagnetic field is generated from the continuous movement of the electrically charged particles inside the body. This is collectively known as Biofield. Biofield Energy Healing Practitioners have the ability to harness the energy from the environment or the "universal energy field", and that can be transmitted into any living or non-living substance (s) around the earth. The process by which the substance receives the Biofield Energy Treatment and responds in a useful way is known as Biofield Energy Healing [13-15].

Biofield (putative energy fields) based energy therapies are used to promote health and are practiced worldwide. The National Center of Complementary and Integrative Health (NCCIH) has recognized and accepted Biofield Energy Healing as a complementary and alternative medicine (CAM) health care approach in addition to other therapies, medicines and practices such as natural products, deep breathing, yoga, Tai Chi, Qi Gong, chiropractic/osteopathic manipulation, meditation, massage, special diets, homeopathy, progressive relaxation, guided imagery, acupressure, acupuncture, relaxation techniques, hypnotherapy, healing touch, movement therapy, pilates, rolfing structural integration, mindfulness, Ayurvedic medicine, traditional Chinese herbs and medicines, naturopathy, essential oils, aromatherapy, Reiki, cranial sacral therapy and applied prayer (as is common in all religions, like Christianity, Hinduism, Buddhism and Judaism) [16]. Scientific study on the various fields such as materials science [17-19], pharmaceuticals [2022], nutraceuticals [23, 24], organic compounds [25-27], microbiology [28-30], agricultural [31, 32], biotechnology [33-35], genetics [36, 37], medical sciences [38, 39], has been proven that Biofield Energy Healing (The Trivedi Effect ${ }^{\mathbb{B}}$ ) has the astounding capability for the alteration of the characteristic properties of the living and non-living substances. Scientific literature reported that the bioavailability of inorganic selenium is lower than the organic forms of selenium such as selenium methionine. But, selenium methionine is easily oxidized to methionine selenoxide, which is poorly absorbed from the gut of the human body [12]. The physicochemical properties such as crystalline structure, crystallite size, particle size, surface area, etc. of a drug molecule play an important role in bioavailability as these factors have the direct influence on the absorption characteristic and stability of the drug [40]. The stability of a solid pharmaceutical with respect to the atmospheric conditions is very important to the pharmaceutical industry, due to the practical involvements of hydrate formation upon processing, formulation, storage, and packaging [41]. Biofield Energy Treatment (The Trivedi Effect ${ }^{\circledR}$ ) has been reported to change the particle size, surface area, crystallite size, spectral and thermal behaviour of an atom/molecule through the possible mediation of neutrinos [42]. Hence, the objective of the current study was to evaluate the effect of the Biofield Energy Healing Treatment on the physicochemical, spectral, and thermal properties of sodium selenate using various analytical techniques include powder X-ray diffraction (PXRD), particle size distribution 
analysis (PSD), Fourier transform infrared (FT-IR) spectrometry, ultraviolet-visible (UV-vis) spectroscopy, thermogravimetric analysis (TGA), and differential scanning calorimetry (DSC).

\section{Materials and Methods}

\subsection{Chemicals and Reagents}

Sodium selenate was procured from Alfa Aesar, USA. All other chemicals used in the experiment were of analytical grade available in India.

\subsection{Energy of Consciousness Healing Treatment Strategies}

Sodium selenate was one of the components of the herbomineral formulation, and it was used independently for the current analysis. One part of the test compound was treated with the Biofield Energy (The Trivedi Effect ${ }^{\circledR}$ ) by renowned Biofield Energy Healers and defined as The Trivedi Effect ${ }^{\circledR}$ - Energy of Consciousness Healing Treated sodium selenate, while the second part of the compound did not receive any sort of treatment and defined as untreated or control sodium selenate. This The Trivedi Effect ${ }^{\mathbb{R}}$ treatment was provided through a group of eighteen renowned Biofield Energy Healers who participated in this study and performed The Trivedi Effect ${ }^{(\mathbb{R}}$ - Energy of Consciousness Healing Treatment remotely to the test compound. Eleven of the Biofield Energy Healers were located in the U. S. A., four in Canada, one in Ireland, one in the United Kingdom, and one in Russia performed the Biofield Energy Treatment on the test compound that was located in the research laboratory of GVK Biosciences Pvt. Ltd., Hyderabad, India. The Trivedi Effect $^{\circledR}$ treatment was provided for 5 minutes through the Healer's Unique Energy Transmission process remotely to the test compound under the laboratory conditions. None of the Biofield Energy Healers in this study visited the laboratory in person, nor had any contact with the test sample. Similarly, the control compound was subjected to "sham" healers for 5 minutes, under the same laboratory conditions. The sham healer did not have any knowledge about The Trivedi Effect ${ }^{\circledR}$ - Energy of Consciousness Healing Treatment. After that, the treated and untreated samples were kept in similar sealed conditions were characterized thoroughly by PXRD, PSD, FT-IR, UV-visible spectroscopy, TGA, and DSC analysis.

\subsection{Characterization}

\subsubsection{Powder X-ray Diffraction (PXRD) Analysis}

The PXRD analysis was accomplished on PANalytical X'pert Pro powder X-ray diffractometer system. The X-ray of wavelength $1.54056 \AA$ was used. The data was collected in

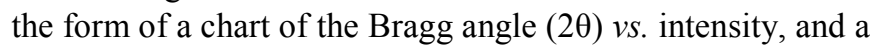
detailed table containing information on peak intensity counts, d value $(\AA)$, relative intensity (\%), full width half maximum (FWHM) $\left(\theta^{\circ}\right)$. From the XRD results, the crystallite size $(G)$ was calculated using $X^{\prime}$ 'pert data collector and X'pert high score plus processing software.
The average crystallite size $(\mathrm{G})$ was calculated from the Scherrer equation (Eq. 1) given below [43, 44]. The method was based on the width of the diffraction patterns obtained in the X-ray reflected the crystalline region.

$$
\mathrm{G}=\mathrm{k} \lambda /(\mathrm{b} \operatorname{Cos} \theta)
$$

Where, $\mathrm{k}$ is the equipment constant $(0.5), \lambda$ is the $\mathrm{X}$-ray wavelength $(0.154 \mathrm{~nm})$; b in radians is the full-width at half of the peaks and $\theta$ the corresponding Bragg angle.

Percent change in crystallite size $(G)$ was calculated using the following equation 2 :

$$
\% \text { change in crystallite size }=\frac{\left[\mathrm{G}_{\text {Treated }}-\mathrm{G}_{\text {Control }}\right]}{\mathrm{G}_{\text {Control }}} \times 100
$$

Where, $\mathrm{G}_{\text {control }}$ and $\mathrm{G}_{\text {treated }}$ denote the crystallite size of the control and treated powder samples, respectively.

\subsubsection{Particle Size Distribution (PSD) Analysis}

The average particle size and particle size distribution were analyzed using Malvern Mastersizer 2000, UK with a detection range between $0.01 \mu \mathrm{m}$ to $3000 \mu \mathrm{m}$. The sample unit was filled with dispersant medium and operated the stirrer at $2500 \mathrm{rpm}$. Alignment of the optics was done and taken the background measurement. After the background measurement, the sample was added to the sample unit with constant monitoring the obscuration and stopped the addition of sample when the obscuration reached in between $15 \%$ and $20 \%$. When the obscuration was stable, the measurement was taken twice and the average was taken of two measurements. The average histogram of the two measurements was recorded. The print out of the average histogram of the two measurements will be documented. Along with histogram, the data will be presented in the table format which include particle size $(\mu \mathrm{m})$. Also, the values at below $10 \%$ level $\left(\mathrm{d}_{10}\right)$, $50 \%$ level $\left(\mathrm{d}_{50}\right)$, and $90 \%$ level $\left(\mathrm{d}_{90}\right)$ were calculated from the histogram and the calculations such as surface area $\left(\mathrm{m}^{2} / \mathrm{g}\right)$ were done by using software Mastersizer 2000. Percent change in particle size $(d)$ for at below $10 \%$ level $\left(d_{10}\right), 50 \%$ level $\left(\mathrm{d}_{50}\right)$, and $90 \%$ level $\left(\mathrm{d}_{90}\right)$ was calculated using following equation 3 :

$$
\% \text { change in particle size }=\frac{\left[\mathrm{d}_{\text {Treated }}-\mathrm{d}_{\text {Control }}\right]}{\mathrm{d}_{\text {Control }}} \times 100
$$

Where, $d_{\text {Control }}$ and $d_{\text {Treated }}$ are the particle size $(\mu \mathrm{m})$ for at below $10 \%$ level $\left(\mathrm{d}_{10}\right), 50 \%$ level $\left(\mathrm{d}_{50}\right)$, and $90 \%$ level $\left(\mathrm{d}_{90}\right)$ of the control and treated samples, respectively.

Percent change in surface area (S) was calculated using following equation 4 :

$$
\% \text { change in surface area }=\frac{\left[\mathrm{S}_{\text {Treated }}-\mathrm{S}_{\text {Control }}\right]}{\mathrm{S}_{\text {Control }}} \times 100
$$

Where, $\mathrm{S}_{\text {Control }}$ and $\mathrm{S}_{\text {Treated }}$ are the surface area of the control and treated samples, respectively.

\subsubsection{Fourier Transform Infrared (FT-IR) Spectroscopy}

FT-IR spectroscopy of sodium selenate was performed on Spectrum two (Perkin Elmer, USA) Fourier transform infrared spectrometer with the frequency array of 400-4000 
$\mathrm{cm}^{-1}$ by using pressed $\mathrm{KBr}$ disk technique.

\subsubsection{Ultra Violet-Visible (UV-Vis) Spectroscopy}

The UV-Vis spectral analysis was carried out using Shimadzu UV-2450 with UV Probe, Japan. The spectrum was recorded using $1 . \mathrm{cm}$ quartz cell that has a slit width of $1.0 \mathrm{~nm}$. The wavelength range chosen for recording the spectra was $190-800 \mathrm{~nm}$. The absorbance spectra (in the range of 0.2 to 0.9 ) and wavelength of maximum absorbance $\left(\lambda_{\max }\right)$ were recorded.

\subsubsection{Thermal Gravimetric Analysis (TGA)}

The analysis was performed using Instrument TGA Q50 (TA Instruments, USA) thermo gravimetric analysis at a heating rate of $10^{\circ} \mathrm{C} / \mathrm{min}$ from room temperature i.e. $30^{\circ} \mathrm{C}$ to $900^{\circ} \mathrm{C}$ under the nitrogen atmosphere, $11.86 \mathrm{mg}$ of samples were taken on the Platinum pan. In TGA, the weight loss for each step was recorded in grams as well as in percent loss with respect to the initial weight. Also, the onset, endset, and peak temperature for each step were recorded in TGA. Percent change in weight loss (W) was calculated using following equation 5 :

$$
\% \text { change in weight loss }=\frac{\left[\mathrm{W}_{\text {Treated }}-\mathrm{W}_{\text {Control }}\right]}{\mathrm{W}_{\text {Control }}} \times 100
$$

Where, $\mathrm{W}_{\text {Control }}$ and $\mathrm{W}_{\text {Treated }}$ are the weight loss of the control and treated samples, respectively.

\subsubsection{Differential Scanning Calorimetry (DSC)}

The analysis was performed using the DSC Q20 (TA Instruments, USA) differential scanning calorimeter.2.70 mg of sample was weighed and sealed in aluminium pans and equilibrated at $25^{\circ} \mathrm{C}$ and heated up to $600^{\circ} \mathrm{C}$ at the heating rate of $10^{\circ} \mathrm{C} / \mathrm{min}$ under nitrogen gas as purge atmosphere with the flow rate of $50 \mathrm{~mL} / \mathrm{min}$. The value for onset, endset, peak temperature, peak height $(\mathrm{mJ}$ or $\mathrm{mW})$, peak area, and change in heat $(\mathrm{J} / \mathrm{g})$ for each peak was recorded. Percent change in melting point $(\mathrm{T})$ was calculated using following equation 6:

$$
\% \text { change in melting point }=\frac{\left[\mathrm{T}_{\mathrm{Treated}}-\mathrm{T}_{\text {Control }}\right]}{\mathrm{T}_{\text {Control }}} \times 100
$$

Where, $\mathrm{T}_{\text {Control }}$ and $\mathrm{T}_{\text {Treated }}$ are the melting point of the control and treated samples, respectively.

Percent change in latent heat of fusion $(\Delta \mathrm{H})$ was calculated using following equation 7 :

$$
\% \text { change in Latent heat of fusion }=\frac{\left[\Delta \mathrm{H}_{\text {Treated }}-\Delta \mathrm{H}_{\text {Control }}\right]}{\Delta \mathrm{H}_{\text {Control }}} \times 100
$$

Where, $\Delta \mathrm{H}_{\text {Control }}$ and $\Delta \mathrm{H}_{\text {Treated }}$ are the latent heat of fusion of the control and treated samples, respectively.

\section{Results and Discussion}

\subsection{Powder X-Ray Diffraction (PXRD) Analysis}

Powder X-ray diffraction analysis was conducted to analyse the crystalline pattern of the control and treated samples of sodium selenate (Figure 1 and Table 1). Diffractogram of the control sodium selenate showed the

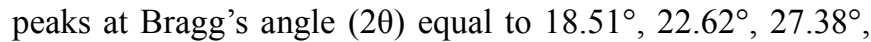
$28.50^{\circ}, 31.14^{\circ}, 32.74^{\circ}, 34.41^{\circ}, 37.33^{\circ}, 45.18^{\circ}, 46.01,47.49^{\circ}$, and $48.92^{\circ}$. Similarly, the diffractogram of the treated sodium selenate exhibited the peaks at $2 \theta$ equal to $18.64^{\circ}$, $22.75^{\circ}, 27.51^{\circ}, 28.63^{\circ}, 31.27^{\circ}, 32.87^{\circ}, 34.53^{\circ}, 37.46^{\circ}$, $45.30^{\circ}, 46.13,47.61^{\circ}$, and $49.04^{\circ}$. The PXRD diffractograms showed the sharp and intense peaks in both the samples and no broadening of peaks were evident, which indicated that both the samples were crystalline in nature. However, the diffractogram of the treated sodium selenate showed the peaks with increased intensity compared with the control sample (Table 1).

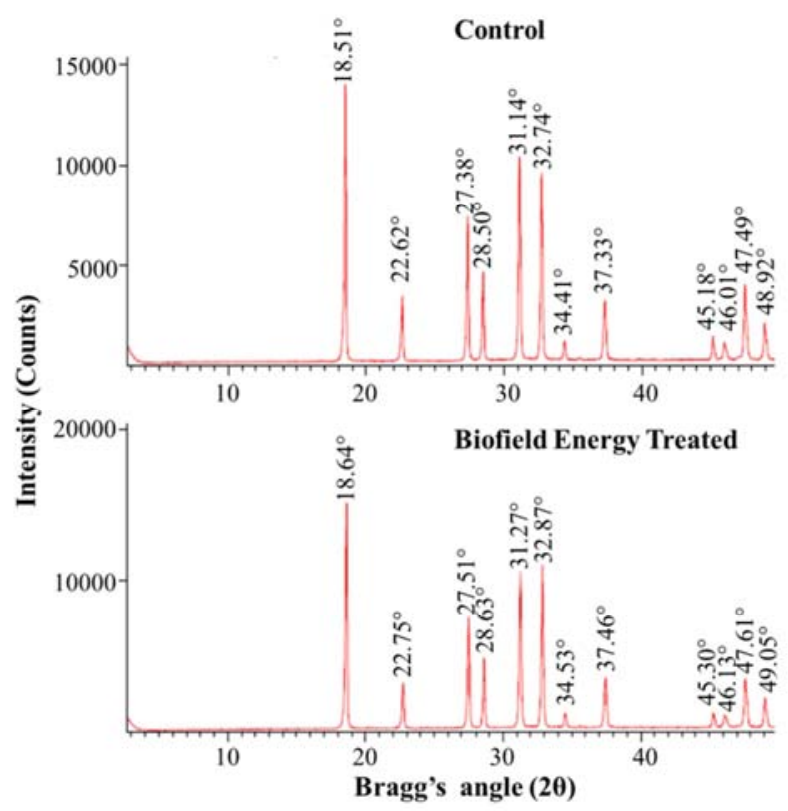

Figure 1. PXRD diffractograms of the control and Biofield Energy Treated sodium selenate. 
Table 1. PXRD data for the control and Biofield Energy Treated sodium selenate.

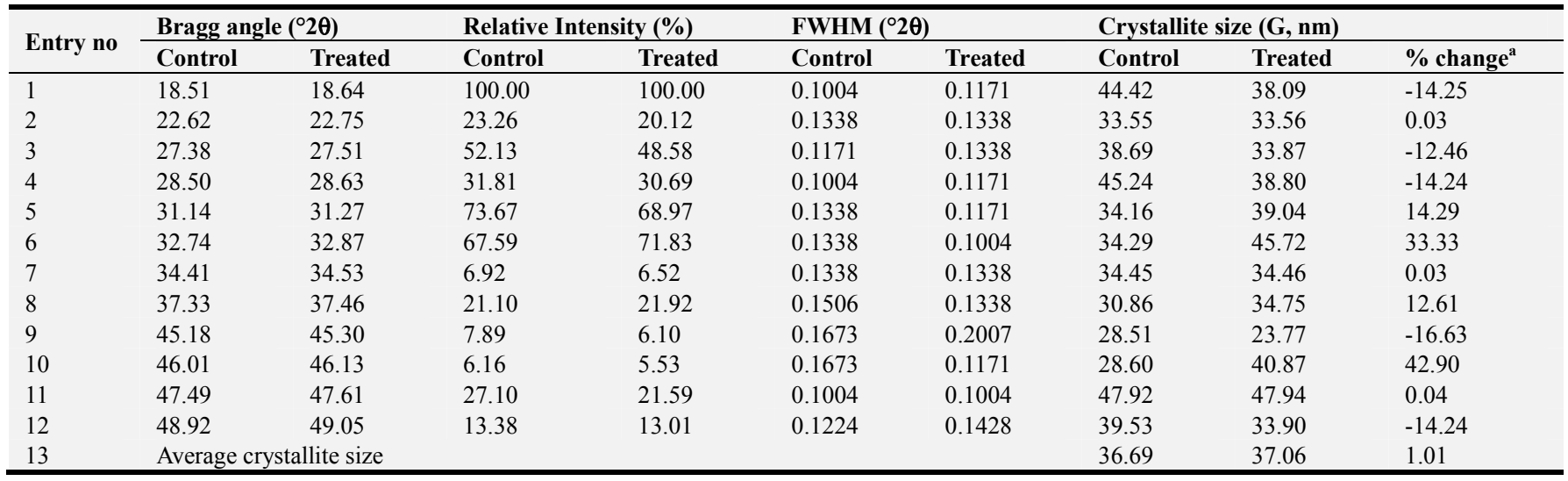

FMHM: Full width at half maximum, ${ }^{\text {a }}$ denotes the percentage in the crystallite size of Biofield Energy Treated sample with respect to the control sample.

The most intense peaks were observed at $2 \theta$ equal to $18.51^{\circ}$ and $18.64^{\circ}$ in the control and treated diffractograms, respectively (Table 1 , entry 1 ). It indicated that the relative intensities of PXRD peaks were altered in the treated sodium selenate compared with the control sample. The changes in crystal morphology cause the alteration in relative intensities of the peaks [44]. Thus, it is presumed that the energy transferred through The Trivedi Effect ${ }^{\circledR}$ - Biofield Energy Treatment probably altered the shape and size of molecules of the treated sample and that might be responsible for the alteration in relative intensities in the treated sample compared with the control sample. The average crystallite size was calculated using Scherrer equation [43]. The PXRD analysis of the treated sample showed the significant alteration of the crystallite size in the range of $-16.63 \%$ to $42.90 \%$ compared with the control sample. The crystallite size of the treated zinc chloride at $2 \theta$ equal to nearly $18.64^{\circ}$, $27.51^{\circ}, 28.63^{\circ}, 45.30^{\circ}$ and $49.05^{\circ}$ (Table 1 ; entry $1,3,4,9$, and 12 ) were significantly decreased in the range of $12.46 \%$ to $16.63 \%$ compared with the control sample. Consequently, the crystallite size of the treated zinc chloride at $2 \theta$ equal to $22.75^{\circ}, 31.27^{\circ}, 32.87^{\circ}, 34.53^{\circ}, 37.46^{\circ}, 46.13$, and 47.61 , were increased in the range of $0.04 \%$ to $42.9 \%$ compared with the control sample (Table 1; entry 2, 5, 6, 7, 8, 10, and 11). Overall, the average crystallite size of the treated sodium selenate was increased by $1.01 \%$ compared with the control sample. As per the literature, the increase in the lattice strain may reduce the crystallite size of the sample [45]. Therefore, it can be hypothesized that The Trivedi Effect ${ }^{\circledR}$ - Biofield Energy Treatment might induce some lattice strain within the treated molecules of sodium selenate, resulting in fracture of grains into sub-grains that could lead to the decrease in the crystallite size of the treated sample compared with the control sample. Alteration in crystallite size of the treated sample might have the influence on its solubility profile compared with the control sample.

\subsection{Particle Size Distribution (PSD) Analysis}

Particle sizes of the control and treated sodium selenate were investigated, and the results are presented in Table 2. It was observed that The Trivedi Effect ${ }^{\circledR}$ - Biofield Energy Treatment has significantly decreased the average particle size $\mathrm{d}_{10}, \mathrm{~d}_{50}$, and $\mathrm{d}_{90}$ value of sodium selenate with respect to the control sample. The sizes at below $10 \%$ level $\left(\mathrm{d}_{10}\right), 50 \%$ level $\left(\mathrm{d}_{50}\right)$, and $90 \%$ level $\left(\mathrm{d}_{90}\right)$ were decreased significantly by $6.14 \%, 16.56 \%$, and $18.82 \%$, respectively in the treated sample compared with the control sample. The control sample exhibited the surface area of $0.57 \mathrm{~m}^{2} / \mathrm{g}$ and it was increased to $0.63 \mathrm{~m}^{2} / \mathrm{g}$ in the treated sodium selenate. The results indicated a significant increase in surface area by $10.52 \%$ in the treated sample compared with the control sample. The particle size and the surface area have the major influence on solubility, absorption, dissolution, and bioavailability of the nutraceutical/pharmaceutical compounds [46]. The surface energy is the driving factor for dissolution efficiency and surface energy was mainly influenced by surface area and chemical affinity [47, 48]. Thus, it is predicted that The Trivedi Effect ${ }^{\circledR}$ - Biofield Energy Treated sodium selenate might be absorbed in faster rate from the gut and thus, can offer more bioavailability compared with the untreated sample.

Table 2. Particle size data $\left(d_{10,} d_{50}\right.$, and $\left.d_{90}\right)$ and surface area of the control and Biofield Energy Treated sodium selenate.

\begin{tabular}{lllll}
\hline Test Item & $\mathbf{d}_{\mathbf{1 0}}(\boldsymbol{\mu m})$ & $\mathbf{d}_{\mathbf{5 0}}(\boldsymbol{\mu m})$ & $\mathbf{d}_{\mathbf{9 0}}(\boldsymbol{\mu m})$ & Surface $\operatorname{area}\left(\mathbf{m}^{2} / \mathbf{g}\right)$ \\
\hline $\begin{array}{l}\text { Control } \\
\text { Biofield Energy }\end{array}$ & 4.428 & 18.876 & 58.456 & 0.57 \\
$\begin{array}{l}\text { Treated } \\
\text { \% Change }^{\mathrm{a}}\end{array}$ & 4.156 & 15.751 & 47.455 & 0.63 \\
\hline
\end{tabular}

a denotes the percentage change in the particle size data $\left(\mathrm{d}_{10}, \mathrm{~d}_{50}\right.$, and $\left.\mathrm{d}_{90}\right)$ and surface area of Biofield Energy Treated sample with respect to the control sample.

\subsection{Fourier Transform Infrared (FT-IR) Spectroscopy}

The FT-IR spectra of the control and Biofield Energy Treated samples of sodium selenate are presented in Figure 2. The spectra showed the $\mathrm{O}-\mathrm{H}$ stretching vibration at $3453 \mathrm{~cm}^{-1}$ and $3439 \mathrm{~cm}^{-1}$ and bending vibration at $1721 \mathrm{~cm}^{-1}$ and 1723 $\mathrm{cm}^{-1}$ in the control and treated samples, respectively. It is due to the water molecules, which are incorporated into the lattice structure of the crystalline inorganic compounds produced 
the characteristic absorption bands $[49,50]$. According to the literature, the FT-IR of metal oxide (i. e. $\mathrm{Zn}=\mathrm{O})$ shows the peak in the range of $1010-850 \mathrm{~cm}^{-1}$ (stretching) [51]. The spectra showed the sharp and strong peak at $888 \mathrm{~cm}^{-1}$ and $887 \mathrm{~cm}^{-1}$ (Figure 2) due to the Se-O stretching in the fingerprint region for both the control and treated samples of sodium selenate, respectively. The fingerprint region of the treated sample was remained same as it was in the control sample. The analysis revealed that structure integrity of the treated sodium selenate remained unaffected with respect to the control sample.

\subsection{Ultra Violet-Visible (UV-Vis) Spectroscopy}

The UV-visible spectra of the control and treated samples
(Figure 3 ) showed the maximum absorbance $\left(\lambda_{\max }\right)$ at 204.8 $\mathrm{nm}$ and $204.9 \mathrm{~nm}$ respectively, which showed a minor shift of absorbance maxima from 2.4626 in control to 2.5152 in the treated sample. The UV-visible absorbance occurred due to excitation of electrons from highest energy occupied molecular orbital (HOMO) to lowest energy unoccupied molecular orbital (LUMO) [52-54]. It indicated that the energy gap between the HOMO and LUMO in the treated sample was similar compared with the control sample. The UV-visible analysis exhibited no change in the $\lambda_{\max }$ of the treated sodium selenate compared with the control sample. It is anticipated that the structural configuration of the sodium selenate remained unchanged due to The Trivedi Effect ${ }^{\circledR}$ Biofield Energy Treatment.

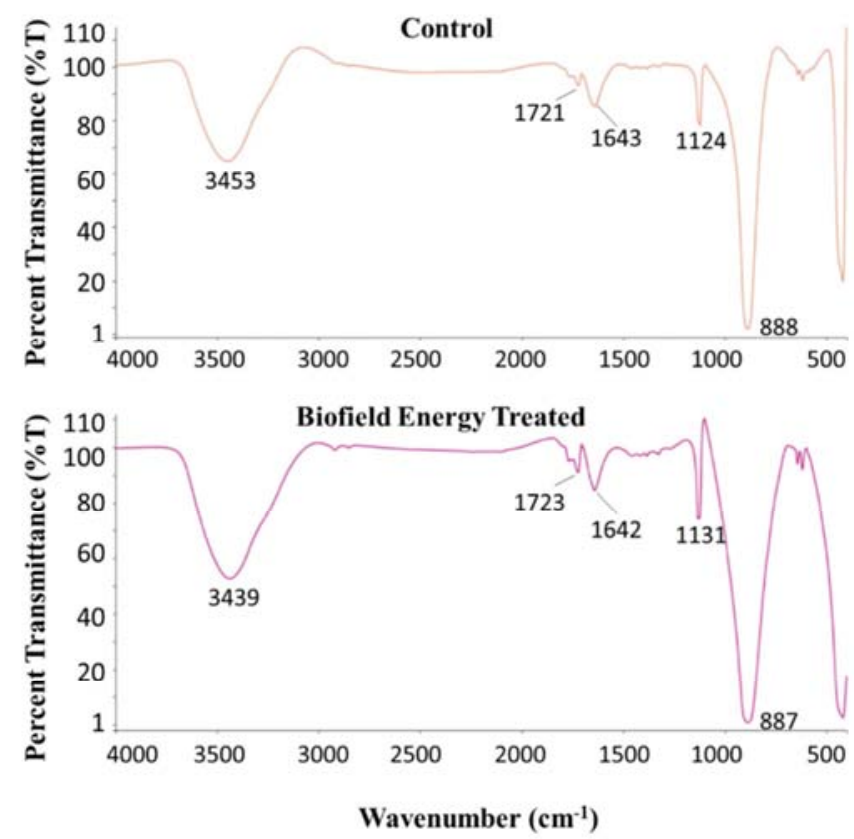

Figure 2. FT-IR spectra of the control and Biofield Energy Treated sodium selenate.

\subsection{Thermogravimetric Analysis (TGA)}

The TGA thermograms of the both control and treated samples and their thermal analysis data are shown in Figure 4 and Table 3, respectively. The TGA thermograms of control and treated samples were exhibited two steps of thermal degradation. The control and treated samples had lost weight by $6.87 \%$ and $6.95 \%$, respectively of their total original weight during the thermal degradation process. The total weight loss was slightly increased by $1.16 \%$ in the treated sodium selenate compared with the control sample.

Table 3. Thermal degradation data of the control and Biofield Energy Treated sodium selenate.

\begin{tabular}{llllll}
\hline \multirow{2}{*}{ S. No. } & \multicolumn{3}{l}{ Temperature $\left({ }^{\circ} \mathbf{C}\right)$} & $\%$ Weight loss & \multirow{2}{*}{$\%$} \\
\cline { 2 - 5 } & Control & Treated & Control & Treated & \\
\hline $1^{\text {st }}$ step of degradation & 101.01 & 104.45 & 0.14 & 0.14 & 0.00 \\
$2^{\text {nd }}$ step of degradation & 896.18 & 896.04 & 6.73 & 6.81 & 1.19 \\
Total weight loss & - & - & 6.87 & 6.95 & 1.16 \\
\hline
\end{tabular}

a denotes the percentage change in the weight loss of Biofield Energy Treated sample with respect to the control sample.

\subsection{Differential Scanning Calorimetry (DSC) Analysis}

Measurement of melting point and latent heat of fusion $(\Delta \mathrm{H})$ of the control and treated samples of sodium selenate were performed using DSC analysis (Figure 5 and Table 4). The onset and endset temperatures of the control sample were 584.08 and $595.66^{\circ} \mathrm{C}$, respectively, whereas these temperatures were found in the treated sample at $584.18{ }^{\circ} \mathrm{C}$ and $596.19^{\circ} \mathrm{C}$, respectively. The melting point of the treated sodium selenate $\left(588.69^{\circ} \mathrm{C}\right)$ was decreased slightly by $0.02 \%$ compared with the control sample $\left(588.82^{\circ} \mathrm{C}\right)$. The latent heat of fusion was significantly increased by $6.37 \%$ in the treated sample $(103.4 \mathrm{~J} / \mathrm{g})$ compared with the control sample $(97.21 \mathrm{~J} / \mathrm{g})$. Thus, the treated sodium selenate needed more energy in the form of latent heat of fusion in order to undergo the process of melting after Biofield Energy Treatment [55]. It is hypothesized that the Biofield Energy Healing might induce the intermolecular force in the Biofield Energy Treated sodium selenate molecules, which possibly cause the elevation of the latent heat of fusion. 

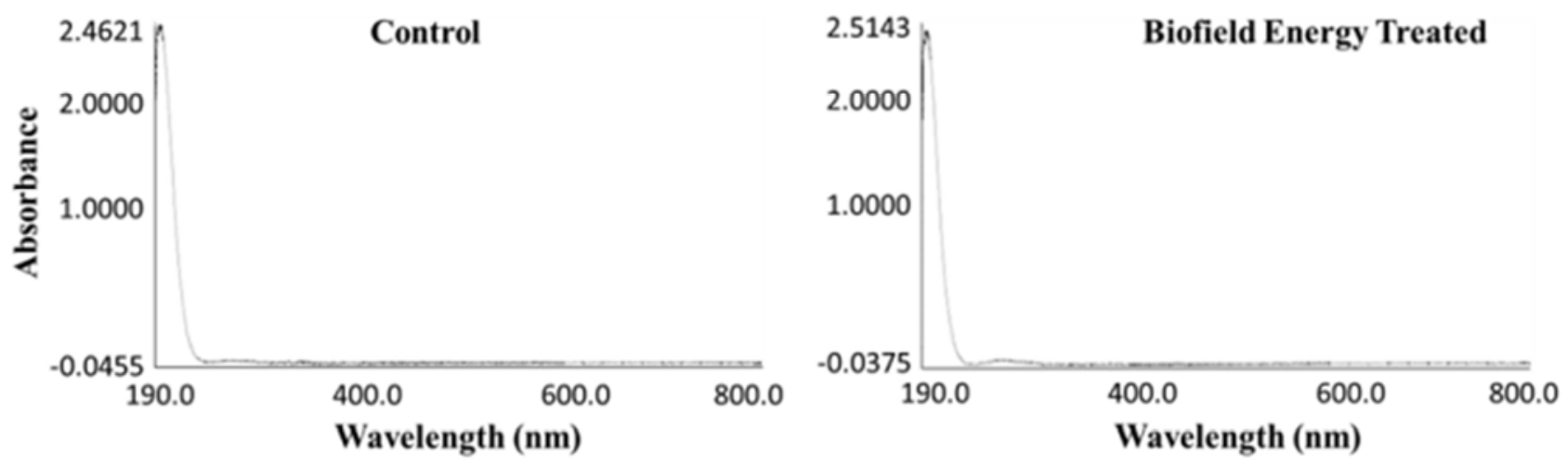

Figure 3. UV-vis spectra of the control and Biofield Energy Treated sodium selenate.
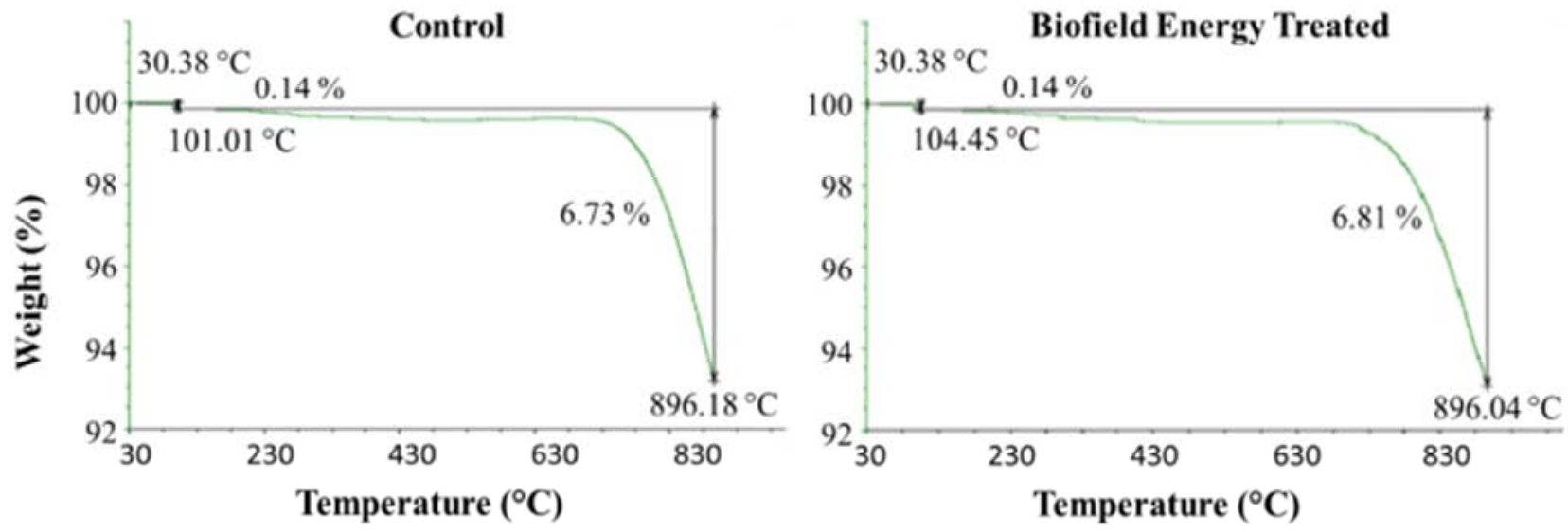

Figure 4. TGA thermograms of the control and Biofield Energy Treated sodium selenate.
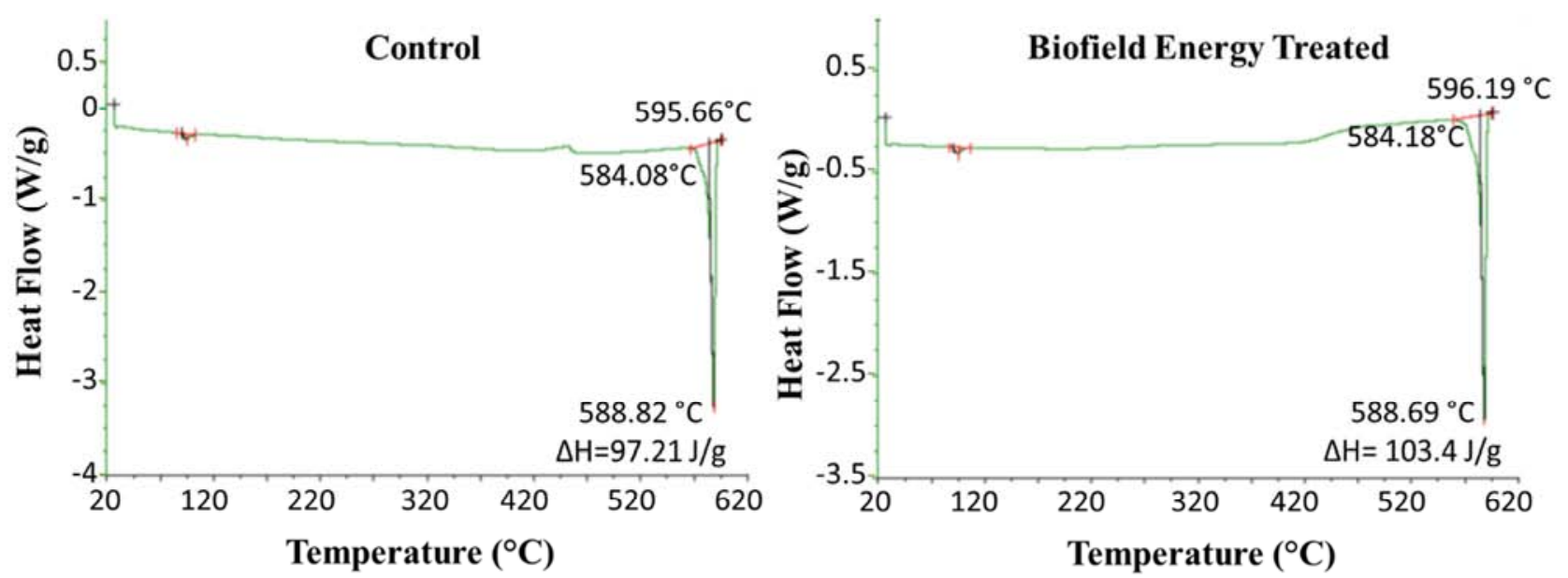

Figure 5. DSC thermograms of the control and Biofield Energy Treated sodium selenate.

Table 4. The latent heat of fusion $(\mathrm{J} / \mathrm{G})$ and melting point $\left({ }^{\circ} \mathrm{C}\right)$ values of the control and Biofield Energy Treated sodium selenate.

\begin{tabular}{|c|c|c|c|c|}
\hline Sample & Latent heat of fusion $(\Delta \mathrm{H}) \mathrm{J} / \mathrm{g}$ & $\begin{array}{l}\text { Onset melting temperature } \\
\left(\mathbf{T}_{\text {onset }}\right)^{\circ} \mathrm{C}\end{array}$ & $\begin{array}{l}\text { Peak melting temperature } \\
\left(\mathrm{T}_{\text {peak }}\right)^{\circ} \mathrm{C}\end{array}$ & $\begin{array}{l}\text { Endset melting } \\
\text { temperature }\left(\mathrm{T}_{\text {endset }}\right){ }^{\circ} \mathrm{C}\end{array}$ \\
\hline Control & 97.21 & 584.08 & 588.82 & 595.66 \\
\hline Trivedi Effect ${ }^{\circledR}$ Treated & 103.4 & 584.18 & 588.69 & 596.19 \\
\hline$\%$ Change $^{\mathrm{a}}$ & 6.37 & 0.02 & -0.02 & 0.09 \\
\hline
\end{tabular}

$\mathrm{T}_{\text {onset }}$ : Onset melting temperature, $\mathrm{T}_{\text {peak }}$ : Peak melting temperature, $\mathrm{T}_{\text {endset }}$ : Endset melting temperature, $\Delta \mathrm{H}$ : Latent heat of fusion, ${ }^{\mathrm{a}}$ denotes the percentage change of Biofield Energy Treated sample with respect to the control sample. 


\section{Conclusions}

The Trivedi Effect ${ }^{\circledR}$ - Energy of Consciousness (Biofield Energy Healing) has shown significant impact on the physicochemical and thermal properties of sodium selenate. The PXRD analysis of the treated sample showed the significant alteration of the crystallite size in the range of $16.63 \%$ to $42.9 \%$ compared with the control sample. However, the average crystallite size of the treated sodium selenate was altered compared with the control sample. Particle size at $\mathrm{d}_{10}, \mathrm{~d}_{50}$ and $\mathrm{d}_{90}$ was significantly decreased by $6.14 \%, 16.56 \%$, and $18.82 \%$, respectively in the treated sample compared with the control sample. Consequently, the surface area of the treated sodium selenate was significantly increased by $10.52 \%$ compared with the control sample. The TGA analysis of the control and treated samples exhibited two steps of thermal degradation, and the total weight loss was increased by $1.16 \%$ in the treated sample compared with the control sample. The DSC analysis revealed a significant elevation of the latent heat of fusion $(\Delta \mathrm{H})$ by $6.37 \%$ in the treated sodium selenate compared with the control sample. Therefore, the treated sodium selenate would be thermally more stable and advantageous in the long-term storage stability compared with the control sample. The Trivedi Effect $^{\circledR}$ - Biofield Energy Healing Treatment has shown an impact on the reduction in the particle size, an increase in the surface area and increase in the latent heat of fusion of sodium selenate. Hence, The Trivedi Effect ${ }^{\circledR}$, a new proprietary method that can be used to enhance the bioavailability of sodium selenate through changing the physicochemical and thermal properties. Thus, The Trivedi Effect $^{\circledR}$ Energy Healing, could be a useful approach in the design of better nutraceutical and/or pharmaceutical formulations that can offer significant therapeutic responses against various diseases such as diabetes mellitus, allergies and septic shock; stress-related disorders like sleep disorder, insomnia, anxiety, depression, Attention Deficit Disorder (ADD), Attention Deficit Hyperactive Disorder (ADHD), mental restlessness (mind chattering), brain frog, low libido, impotency, lack of motivation, mood swings, fear of the future, confusion, migraines, headaches, forgetfulness, overwhelm, loneliness, worthlessness, indecisiveness, frustration, irritability, chronic fatigue, obsessive/compulsive behavior and panic attacks; inflammatory diseases and immunological disorders like Lupus, Systemic Lupus Erythematosus, Hashimoto Thyroiditis, Type 1. Diabetes, Asthma, Chronic peptic ulcers, Tuberculosis, Hepatitis, Chronic active hepatitis, Celiac Disease (gluten-sensitive enteropathy), Addison Disease, Crohn's disease, Graves' Disease, Pernicious and Aplastic Anemia, Sjogren Syndrome, Irritable Bowel Syndrome (IBS), Multiple Sclerosis, Rheumatoid arthritis, Chronic periodontitis, Ulcerative colitis, Chronic sinusitis, Myasthenia Gravis, Atherosclerosis, Vasculitis, Dermatitis, Diverticulitis, Rheumatoid Arthritis, Reactive Arthritis, Alopecia Areata, Psoriasis, Scleroderma, Fibromyalgia, Chronic Fatigue
Syndrome and Vitiligo; aging-related diseases like cardiovascular disease, arthritis, cancer, Alzheimer's disease, dementia, cataracts, osteoporosis, diabetes, hypertension, glaucoma, hearing loss, Parkinson's Disease, Huntington's Disease, Prion Disease, Motor Neurone Disease, Spinocerebellar Ataxia, Spinal muscular atrophy, Amyotrophic lateral sclerosis, Friedreich's Ataxia and Lewy Body Disease, chronic infections and much more.

\section{Abbreviations}

DSC: Differential scanning calorimetry, FT-IR: Fourier transform infrared, FWHM: Full width half maximum, $\Delta \mathrm{H}$ : Latent heat of fusion, HOMO: Highest energy occupied molecular orbital, LUMO: Lowest energy unoccupied molecular orbital, PSD: Particle size distribution, $\mathrm{T}_{\text {onset }}$ : Onset melting temperature, $\mathrm{T}_{\text {peak }}$ : Peak melting temperature, $\mathrm{T}_{\text {endset }}$ : Endset melting temperature, TGA: Thermogravimetric analysis, UV-vis: Ultra-violet Visible spectroscopy, PXRD: Powder X-ray diffraction

\section{Acknowledgements}

The authors are grateful to GVK Biosciences Pvt. Ltd., Hyderabad, India, Trivedi Science, Trivedi Global, Inc. and Trivedi Master Wellness for their support throughout the work.

\section{References}

[1] Basnayake RST (2001) Inorganic selenium and tellurium speciation in aqueous medium of biological samples, Master of Science (Chemistry), December 2001, Sam Houston State University, Huntsville, Texas, $60 \mathrm{pp}$.

[2] Soruraddin MH, Heydari R, Puladvand M, Zahedi MM (2011) A new spectrophotometric method for determination of selenium in cosmetic and pharmaceutical preparations after preconcentration with cloud point extraction. Int J Anal Chem 2011: 729651.

[3] UmyFsová D, Vítová M, Doušková I, Bišová K, Hlavová M, Č́žková M, Machát J, Doucha J, Zachleder V (2009) Bioaccumulation and toxicity of selenium compounds in the green alga Scenedesmus quadricauda. BMC Plant Biol 9: 58.

[4] Gonzalez CM, Hernandez J, Peralta-Videa JR, Botez CE, Parsons JG, Gardea-Torresdey JL (2012) Sorption kinetic study of selenite and selenate onto a high and low pressure aged iron oxide nanomaterial. J Hazard Mater 211-212: 138145 .

[5] Sabaty M, Avazeri C, Pignol D, Vermeglio A (2001) Characterization of the reduction of selenate and tellurite by nitrate reductases. Appl Environ Microbiol 67: 5122-5126.

[6] Van Eersel J, Ke YD, Liu X, Delerue F, Kril JJ, Götz J, Ittner LM (2010) Sodium selenate mitigates tau pathology, neurodegeneration, and functional deficits in Alzheimer's disease models. Proc Natl Acad Sci USA 107: 13888-13893. 
[7] Salama RM, Schaalan MF, Elkoussi AA, Khalifa AE (2013) Potential utility of sodium selenate as an adjunct to metformin in treating type II diabetes mellitus in rats: A perspective on protein tyrosine phosphatase. Biomed Res Int 2013: 231378.

[8] Chen P, Wang L, Wang Y, Li S, Shen L, Liu Q, Ni J (2014) Phosphoproteomic profiling of selenate-treated Alzheimer's disease model cells. PLoS ONE 9: e113307.

[9] https://en.ikipedia.org/wiki/Sodium_selenate.

[10] Krieger RI (2001) Handbook of Pesticide Toxicology, $2^{\text {nd }}$ Edn, Volume 1; Academic Press: San Diego, CA.

[11] Hanson B, Lindblom SD, Loeffler ML, Pilon-Smits E (2004) Selenium protects plants from phloem-feeding aphids due to both deterrence and toxicity. New Phytologist 162: 655-662.

[12] Haug A, Graham RD, Christophersen OA, Lyons GH (2007) How to use the world's scarce selenium resources efficiently to increase the selenium concentration in food. Microb Ecol Health Dis 19: 209-228.

[13] Rubik B (2002) The biofield hypothesis: Its biophysical basis and role in medicine. J Altern Complement Med 8: 703-717.

[14] Rivera-Ruiz M, Cajavilca C, Varon J (2008) Einthoven's string galvanometer: The first electrocardiograph. Tex Heart Inst J 35: 174-178.

[15] Nemeth L (2008) Energy and biofield therapies in practice. Beginnings 28: 4-5.

[16] Koithan M (2009) Introducing complementary and alternative therapies. J Nurse Pract 5: 18-20.

[17] Trivedi MK, Branton A, Trivedi D, Nayak G, Panda P, Jana S (2016) Isotopic abundance ratio analysis of 1, 2, 3trimethoxybenzene (TMB) after biofield energy treatment (The Trivedi Effect ${ }^{\mathbb{R}}$ ) using gas chromatography-mass spectrometry. American Journal of Applied Chemistry 4: 132-140.

[18] Trivedi MK, Branton A, Trivedi D, Nayak G, Sethi KK, Jana S (2016) Gas chromatography-mass spectrometry based isotopic abundance ratio analysis of biofield energy treated methyl-2-napthylether (Nerolin). American Journal of Physical Chemistry 5: 80-86.

[19] Trivedi MK, Branton A, Trivedi D, Nayak G, Sethi KK, Jana S (2016) Evaluation of isotopic abundance ratio in biofield energy treated nitrophenol derivatives using gas chromatography-mass spectrometry. American Journal of Chemical Engineering 4. 68-77.

[20] Trivedi MK, Branton A, Trivedi D, Nayak G, Bairwa K, Jana S (2015) Spectroscopic characterization of disulfiram and nicotinic acid after biofield treatment. J Anal Bioanal Tech 6: 265 .

[21] Trivedi MK, Patil S, Shettigar H, Bairwa K, Jana S (2015) Effect of biofield treatment on spectral properties of paracetamol and piroxicam. Chem Sci J 6: 98.

[22] Trivedi MK, Patil S, Shettigar H, Bairwa K, Jana S (2015) Spectroscopic characterization of biofield treated metronidazole and tinidazole. Med chem 5: 340-344.

[23] Trivedi MK, Tallapragada RM, Branton A, Trivedi D, Nayak G, Latiyal O, Mishra RK, Jana S (2015) Physicochemical characterization of biofield treated calcium carbonate powder. American Journal of Health Research 3: 368-375.
[24] Trivedi MK, Tallapragada RM, Branton A, Trivedi D, Nayak G, Latiyal O, Jana S (2015) Physical, atomic and thermal properties of biofield treated lithium powder. J Adv Chem Eng 5. 136.

[25] Trivedi MK, Branton A, Trivedi D, Nayak G, Bairwa K, Jana S (2015) Spectroscopic characterization of disodium hydrogen orthophosphate and sodium nitrate after biofield treatment. J Chromatogr Sep Tech 6: 282.

[26] Trivedi MK, Branton A, Trivedi D, Nayak G, Bairwa K, Jana S (2015) Fourier transform infrared and ultraviolet-visible spectroscopic characterization of ammonium acetate and ammonium chloride: An impact of biofield treatment. Mod Chem appl 3. 163.

[27] Trivedi MK, Branton A, Trivedi D, Nayak G, Bairwa K, Jana S (2015) Impact of biofield treatment on spectroscopic and physicochemical properties of $p$-nitroaniline. Insights in Analytical Electrochemistry 1: 1-8.

[28] Trivedi MK, Patil S, Shettigar H, Mondal SC, Jana S (2015) In vitro evaluation of biofield treatment on Enterobacter cloacae: Impact on antimicrobial susceptibility and biotype. J Bacteriol Parasitol 6. 241.

[29] Trivedi MK, Patil S, Shettigar H, Mondal SC, Jana S (2015) Evaluation of biofield modality on viral load of Hepatitis B and C viruses. J Antivir Antiretrovir 7. 083-088.

[30] Trivedi MK, Branton A, Trivedi D, Nayak G, Gangwar M, Jana S (2015) Improved susceptibility pattern of antimicrobials using vital energy treatment on Shigella sonnei. American Journal of Internal Medicine 3. 231-237.

[31] Trivedi MK, Branton A, Trivedi D, Nayak G, Mondal SC, Jana S (2015) Morphological characterization, quality, yield and DNA fingerprinting of biofield treated alphonso mango (Mangifera indica L.). Journal of Food and Nutrition Sciences 3: $245-250$.

[32] Trivedi MK, Branton A, Trivedi D, Nayak G, Mondal SC, Jana S (2015) Evaluation of plant growth regulator, immunity and DNA fingerprinting of biofield treated mustard seeds (Brassica juncea). Agriculture, Forestry and Fisheries 4: 269274.

[33] Trivedi MK, Branton A, Trivedi D, Nayak G, Singh R, Jana S (2015) Physicochemical and spectroscopic characterization of biofield treated gerbera multiplication medium. Plant 3: 57-63.

[34] Trivedi MK, Branton A, Trivedi D, Nayak G, Mishra RK, Jana S (2015) Characterization of physical, thermal and spectral properties of Biofield Treated date palm callus initiation medium. International Journal of Nutrition and Food Sciences 4: 660-668.

[35] Trivedi MK, Branton A, Trivedi D, Nayak G, Mishra RK, Jana S (2015) Comparative physicochemical evaluation of biofield treated phosphate buffer saline and hanks balanced salt medium. American Journal of BioScience 3. 267-277.

[36] Trivedi MK, Patil S, Shettigar H, Bairwa K, Jana S (2015) Evaluation of phenotyping and genotyping characterization of Serratia marcescens after biofield treatment. J Mol Genet Med 9: 179.

[37] Trivedi MK, Branton A, Trivedi D, Nayak G, Charan S, Jana S (2015) Phenotyping and 16S rDNA analysis after biofield treatment on Citrobacter braakii: A urinary pathogen. J Clin Med Genom 3: 129. 
[38] Trivedi MK, Patil S, Shettigar H, Mondal SC, Jana S (2015) The potential impact of biofield treatment on human brain tumor cells: A time-lapse video microscopy. J Integr Oncol 4. 141.

[39] Trivedi MK, Patil S, Shettigar H, Gangwar M, Jana S (2015) In vitro evaluation of biofield treatment on cancer biomarkers involved in endometrial and prostate cancer cell lines. J Cancer Sci Ther 7. 253-257.

[40] Chereson R (2009) Bioavailability, bioequivalence, and drug selection. In: Makoid CM, Vuchetich PJ, Banakar UV (Eds) Basic pharmacokinetics ( $1^{\text {st }}$ Edn) Pharmaceutical Press, London.

[41] Blagden N, de Matas M, Gavan PT, York P (2007) Crystal engineering of active pharmaceutical ingredients to improve solubility and dissolution rates. Adv Drug Deliv Rev 59: 617630 .

[42] Trivedi MK, Mohan TRR (2016) Biofield energy signals, energy transmission and neutrinos. American Journal of Modern Physics 5: 172-176.

[43] Langford JI, Wilson AJC (1978) Scherrer after sixty years: A survey and some new results in the determination of crystallite size. J Appl Cryst 11: 102-113.

[44] Inoue M, Hirasawa I (2013) The relationship between crystal morphology and XRD peak intensity on $\mathrm{CaSO}_{4} \cdot 2 \mathrm{H}_{2} \mathrm{O}$. J Crystal Growth 380: 169-175.

[45] Balzar D, Audebrand N, Daymond MR, Fitch A, Hewat A, Langford JI, Le Bail A, Louër D, Masson O, McCowan CN, Popa NC, Stephens PW, Toby BH (2004) Size-strain linebroadening analysis of the ceria round-robin sample. J Appl Cryst 37: 911-924.

[46] Sun J, Wang F, Sui Y, She Z, Zhai W, Wang C, Deng Y (2012) Effect of particle size on solubility, dissolution rate, and oral bioavailability: Evaluation using coenzyme $\mathrm{Q}_{10}$ as naked nanocrystals. Int J Nanomed 7: 5733-5744.

[47] Dabhade VV, Tallapragada RMR, Trivedi MK (2009) Effect of external energy on the atomic, crystalline, and powder characteristics of antimony and bismuth powders. Bull Mater Sci 32. 471-479.

[48] Martin AN, Patrick JS (2006) Martin's physical pharmacy and pharmaceutical sciences: Physical chemical and biopharmaceutical principles in the pharmaceutical sciences. Phila: Lippincott Williams and Wilkins.

[49] http://www.kinetics.nsc.ru/chichinin/books/spectroscopy/Stuar t04.pdf.

[50] Rajasree RSR, Gayathri S (2015) Extracellular biosynthesis of selenium nanoparticles using some species of Lactobacillus. Indian J Geo-Marine Sci 43. 766-775.

[51] Coates J (2000) Interpretation of infrared spectra, a practical approach in encyclopedia of analytical chemistry. John Wiley $\&$ Sons Ltd., Chichester.

[52] Zare B, Babaie S, Setayesh N, Shahverdi AR (2013) Isolation and characterization of a fungus for extracellular synthesis of small selenium nanoparticles. Nanomed J 1: 13-19.

[53] Fathi E (2013) Investigation of the effect of sodium selenate on acetylcholinesterase activity under extremely low frequency electromagnetic field. Journal of Biology and Life Science 4. 41-52.

[54] Hesse M, Meier H, Zeeh B (1997) Spectroscopic methods in organic chemistry, Georg Thieme Verlag Stuttgart, New York.

[55] Troy DB, Beringer P (2006) Remington: The science and practice of pharmacy: Instrumental method of analysis. $21^{\text {st }}$ Edition, Chapter 34. 